\title{
Grappling with Misconception: The Role Epistemology Plays on the Debate of African Philosophy
}

\author{
Kwame Ntiamoah Ntim \\ Centre for African and International Studies, University of Cape Coast, Ghana, West Africa
}

\begin{abstract}
This article mainly sought to discuss the role epistemology plays on the debate of African Philosophy. The search for knowledge on the existence of African philosophy have proven to the fact that African philosophy exists. This was made possible by the instrumentality of black Africans who went into serious research for more than five decades, gleaning for materials to show for the reality of African identity. The steps by the black African scholars give reason to the fact that there was the existence of African philosophy. Whatever we consider as philosophical has a lot to do with human reflection on the experience of a society, group or an individual. This reflection is necessitated what we earlier referred to as wonders about compelling problems of life and existence. Such reflection must be critical and logical. As long as anybody or group meets these requirements such a person or group can be said to engage in what is called philosophy. The implication is that whenever our activities conform to the requirements stipulated above, such an activity performed by Africans or those lovers of Africa is called African philosophy. Hence, I submit that what African philosophy is, involves the application of the above categories of conceptual analysis, logic, criticism, and synthesis to the reflections on issues that are of paramount importance to the African needs and ways of life.
\end{abstract}

Keywords: Epistemology, African, Philosophy, Logos, Debate

DOI: $10.7176 / \mathrm{JPCR} / 51-02$

Publication date: January $31^{\text {st }} 2021$

\section{Introduction}

The word "epistemology" is etymologically derived from two Greek words known as epistemme which means knowledge and logos which also means logical discourse. Generally, epistemology is the branch of philosophy which is concerned with the theory of knowledge. Epistemology is the study of the nature of knowledge, justification, and the rationality of belief. Scholars such as Steup and Zalta (2017), Borchert (1967) and Wenning (2011), much debate in epistemology centers on four areas. Firstly, it deals with philosophical analysis of the nature of knowledge and how it relates to such concepts as truth, belief, and justification. Secondly, it pays attention to various problems of skepticism. Thirdly, the sources and scope of knowledge and justified belief, and finally, the criteria for knowledge and justification. Epistemology addresses questions such as: "What makes justified beliefs justified?", "What does it mean to say that we know something?" and fundamentally "How do we know that we know?". It can be said emphatically that epistemology portrays a situation where each individual is given the opportunity to figure out the very things that make up knowledge, the provision of undoubtable proofs for components of knowledge and the reasonability what is classified is knowledge. This write up is geared towards discussing how epistemology plays on the debate of African philosophy. Notwithstanding the stated purposes above, let us take cognisance of the meaning of African philosophy.

\section{Understanding African Philosophy}

There are four renowned African philosophers namely; Kwasi Wiredu, Paulin Hountondji, Oruka Odera and Peter Bodunrin who are of the view that African philosophy is the philosophy done by African philosophers whether such a person is dealing with a particular subject matter that is African or alien to Africa. What this description intends to say is that African philosophy is predominantly meta-philosophy. Appiah (2011) mentioned that African philosophy should include both material on some oral cultures and rather more on the philosophical work that has been done in literate traditions on the African continent, including those that have developed since the introduction of Western philosophical training there.

When perceptions of time, personhood and mind are handled philosophically, for the improvement of the condition of human life of Africans, those who are involved in it are African philosophers and their work can rightly be referred to as African philosophy. Most of the works in African philosophy in the twentieth century were carried out by Africans intellectuals who were trained outside the shores of Africa. It also implies that Africans who do philosophy, people of African descent or others who engaged themselves in the realm of African philosophy are African philosophers. Kwasi Wiredu an African philosopher, who spent so much time and energy to present African philosophy in perfect light, defined African philosophy as folk thought preserved in oral traditions. He strongly holds that African philosophy is critical, individual reflection, using modern logical and conceptual techniques (Wiredu, 1980).

This is not to say that we should equate African philosophy with African folk thought. He argued that African 
folk thoughts are traditional narrations that are uncritical, not analytic and unconstructive. These folk-thoughts cannot enable anyone get to the significance of their meaning in the context of African society. For professional African philosophers, there are two ways of looking at philosophy. First is the attempt to fulfill their professional calling and the need to adapt to social and material needs of society. African philosophy encompasses the traditional African thought such as myths, wise sayings, folklores and the contemporary works of African philosophers trained in Western philosophical tradition which deals with evaluation and analysis of contemporary issues agitating the African mind such as African socio-political philosophy (Omoregbe, 1998). Our confusion was only cleared with Oladipo Olusegun's explanation when he said that they do not enable us to see how these conceptions hang together or to determine their explanatory fruitfulness within the context of their traditional forms of life (Oladipo, 2002).

To accept these folk thoughts would theoretically prevent Africans the opportunity to engage "fruitfully in the activity of modern philosophizing. The presence of these maladies made Wiredu to call for the rejection of the illusion of African folk for African philosophy. The consequence of accepting it could bring about devastating effect on the understanding of Africans. Wiredu says that its acceptance would deny Africans the selfunderstanding they require in order to be able to cope with the exigencies of the cultural transition that is taking place in contemporary Africa.

The attitude of Kwasi Wiredu when considered from the African perspective may be seen as erroneous. It is true that Africans must go out of their cultural cocoon, but the task cannot be carried out in a vacuum. The philosopher who is involved in African philosophy must have to an extent, the ability to rationalize about the happenings in his society. The knowledge must be reasonable. The knowledge should be of elements that are culturally bound. Two things are involved in carrying out this task; one is the fact that methods of scientific oriented thinking be encouraged, and any form of interpretation should take into cognisance the traditional background of the philosophical thought. Simply put philosophy has universal objective, the cultural touch cannot be removed from it.

Sogolo (1990) opines that the issue of whether or not there is African philosophy gives the uncomfortable impression that the question itself is what African philosophy is. To get to the heart of proper articulation of African philosophy the philosopher must be sensitive to the specifics of the African situation in whatever he does. The major task in African philosophy has to do with the methodology of carrying out African philosophy. African philosophy must as a matter of necessity, comprise a set of cultural heritage and at the same time serve a strong need for recreating societal values. It is in this way that African philosophy can become dynamic in content as the existential imports of Africans are always changing from time to time. From above, it can be deduced that African philosophy is philosophy produced by African people, philosophy that presents African worldviews, or philosophy that uses distinct African philosophical methods in all spheres of life.

\section{Debate on African Philosophy}

It is interesting to know from scholars in African philosophy who are indigenous to Africa that, "the debate or controversy on whether or not there exists an African philosophy started with initiative of the German philosopher, William Amo and with the cooperation of other African philosophers like Dubois, Garren, Nkrumah, Azikiwe, Awolowo and Joseph Tarka thet made bold steps to show that, "Africans have the capacity for critical thinking and the capacity to take their intellectual destinies into their hands (Ozumba, 1995). With the wide range of literature on African philosophy the debate is "dead and buried" (Uduigwomen, 1995). The person who dug the grave and buried this controversy in Africa was a foreign priest Placide Tempels in 1945. He presented his work as part of his mission to rehabilitate the black man, his culture and redeem him from the contempt into which he has fallen. This might sound fantastic and encouraging to Africans, most especially the early intellectuals who necessarily had to study in European universities, but the truth of the matter is that African philosophy truly exists. Even though it is not fully expressed in writing we are very sure that it can stand on its own feet and can confidently compete with European philosophy, British philosophy, American philosophy, and so on.

In order to defend the existence of African philosophy, Black Africans went into serious research for more than five decades, gleaning for materials to show for the reality of African identity. In the first place the intention was not to defend the reality of African philosophy, but the unique identity of the African. They were also anxious to prove to the whole world that if given the right opportunity like their other counterparts around the globe, they too can do whatever the others are doing even much better.

We have come to recognise that there are some essential ingredients about what philosophy is. Whatever we consider as philosophical has a lot to do with human reflection on the experience of a society, group or an individual. This reflection is necessitated what we earlier referred to as wonders about compelling problems of life and existence. Such reflection must be critical and logical. As long as anybody or group meets these requirements such a person or group can be said to engage in what is called philosophy. The implication is that whenever our activities conform to the requirements stipulated above, such an activity performed by Africans or those lovers of Africa is called African philosophy. Hence, we submit that what African philosophy is, involves the application 
of the above categories of conceptual analysis, logic, criticism, and synthesis to the reflections on issues that are of paramount importance to the African needs and ways of life. African in this context is not based exclusively on geographical congruity, but also on certain shared values among Africans.

The search for identity, equality and recognition by Africans has actually gingered the peoples to bring out their talents to the growth and progress of the land. But it was after some decades of argument on the possibility of Africa philosophizing and theologizing by a good number of scholars around the globe, that some came to agree that human beings are the same everywhere. Going by this, African philosophy is an attempt by philosophers to make the folklores, myth, sooth sayings, religion, education, socio-political organisations and other aspects of the African culture relevant to African needs not through any dogmatic attachment to standards used in evaluating the African culture or African culture itself, but through creative critical examination and logical methodologies which are not peculiar to the Western culture (Oyeshile, 2008).

This search when traced to the twentieth century gives us the understanding that philosophy is universal in nature. But, Bruce (2010) insists that, African philosophy's development in the twentieth century is both relatively recent, traceable to some seminal texts, and ancient, drawing on cultural form that stretch back in time and space. This clearly shows that philosophy has a cultural underpinning. In the 21 st century, the question of whether there exists a subject of inquiry like African philosophy is no longer relevant. Africans and African scholarship should be interested in standardizing African philosophy.

We are aware of the existence of African philosophy as a field of study. What actually qualifies for an African in terms of philosophy is the content of the philosophy or the identities of the philosophers. This paper has already discussed these qualities earlier on. What is left for us to do is to identify the task African philosophy has put on the philosopher in Africa in the $21^{\text {st }}$ century. Therefore, our effort is not just to defend the existence of African philosophy but more so to integrate the younger scholar in African philosophy to African traditional culture. This is to bring out to the limelight the expectations of African society on those who claim to be African philosophers.

We should be clarified at this point that no group of people has monopoly of knowledge. This means that African philosophy truly exists. Africans can also conceive the reality of God and so on. In fact, the knowledge of God is inherent in the people of Africa. A child in Africa does not need catechism to believe in the existence of God. The child in Africa does not need catechizing to know the goodness of God. Thus, it is completely erroneous to have some of the scholars agree that such realities actually exist in Africa, but it is not possible for Africans to express them or even practice them without relying on European acquired knowledge.

\section{How Epistemology Plays out on the Debate of African Philosophy}

Relating with the above discourses, it can be stated that epistemology plays a very instrumental role on the debate of African philosophy. In this regard, the study of the components that make up the nature of African philosophy have been discussed comprehensively by the African philosophers. The search for knowledge on the existence of African philosophy have proven to the fact that African philosophy exists. This was made possible by the instrumentality of black Africans who went into serious research for more than five decades, gleaning for materials to show for the reality of African identity. The steps by the black African scholars give reason to the fact that there was the existence of African philosophy. By epistemology, African philosophers have been on the urge to make African traditions which include; folklores, myth, sooth sayings, religion, education, socio-political organisations and other aspects of the African culture relevant to African needs. This is done not through any inflexible attachment to standards used in evaluating the African culture or African culture itself, but through creative critical examination and logical methodologies which are not peculiar to the Western culture.

\section{Conclusion}

In conclusion, the above write-up discussed how epistemology plays out on the debate of African philosophy. The various areas of interest have been discussed comprehensively.

\section{REFERENCES}

Borchert, D. M. (1967). Epistemology: Encyclopedia of philosophy. London: Macmillan.

Bruce, B. (2010). African philosophy in the $21^{\text {st }}$ century. Retrieved from https://www.google.com.gh/search

Oladipo, O. (2002). Philosophy and the African experience: The contributions of Kwasi Wiredu. Ibadan: Hope Publications.

Omoregbe, I. J. (1998). African philosophy: Yesterday and today. Oxford: Blackwell.

Oyeshile, O. A. (2008). On defining African philosophy: History, challenges and perspectives. Humanity and Social Sciences Journal, 3(1), 57-64.

Ozumba, G. O. (1995). A recapitulation of Paulin Hountondji's African philosophy: Myth and reality footmarks on African philosophy. Lagos: Obaroh Oginaka Publishers Ltd.

Sogolo, G. S. (1990). Options in African philosophy. Philosophy, 65(2), 40-41.

Steup, M., \& Zalta, E. N. (2017). Stanford encyclopedia of philosophy. New York: Spring. 
Uduigwomen, A. F. (1995). Philosophy and the place of African philosophy: Footmarks on African philosophy. Lagos: Obaroh Oginaka Publishers Ltd.

Wenning. C. J. (2011). Scientific epistemology: How scientists know what they know. New York: Oxford University Press.

Wiredu, K. (1980). Philosophy and an African culture. Cambridge: Cambridge University Press. 